\title{
Corporate Governance dan Kinerja Keuangan
}

\author{
Haniatus Sa'diyah \\ IAIN Salatiga \\ Haniasadiyah@gmail.com
}

\begin{abstract}
This study aims to determine the effect of corporate governance as proxied by the Board of Commissioners, the Board of Independent Commissioners, the Board of Directors and the Sharia Supervisory Board on Financial Performance, through a connecting variable, namely Non Performing Financing (NPF). The sample of this research is using purposive sampling method. The population is 13 Islamic Commercial Banks in Indonesia. The samples obtained were 8 Islamic Commercial Banks. The data is obtained from the quarterly reports of each bank, namely the first quarter of 2017 to the second quarter of 2020. Data analysis and hypothesis testing methods use path analysis using panel data. The results of this study indicate that corporate governance as proxied by the Board of Commissioners, the Independent Commissioner, the Board of Directors and the Sharia Supervisory Board has no effect on financial performance and non-performing financing. This means that higher corporate governance does not affect financial performance or non-performing financing. In this study it was also found that non-performing financing has an effect on financial performance. If nonperforming financing decreases, financial performance will increase. In addition, nonperforming financing in this study cannot be an intervening variable for corporate governance.
\end{abstract} Keywords : DK; DKI; DD; DPS; Financial Performance; Non Performing Financing

\begin{abstract}
ABSTRAK
Penelitian ini bertujuan untuk mengetahui pengaruh corporate governance yang diproksikan dengan Dewan Komisaris, Dewan Komisaris Independen, Dewan Direksi dan Dewan Pengawas Syariah terhadap Kinerja Keuangan, melalui variabel penghubung yaitu Non Performing Financing (NPF). Pengambilan sampel penelitian ini menggunakan metode purposive sampling. Populasi sebanyak 13 Bank Umum Syariah di Indonesia. Sampel yang diperoleh sebanyak 8 Bank Umum Syariah. Data diperoleh dari laporan triwulan masingmasing bank yaitu triwulan pertama tahun 2017 sampai triwulan kedua tahun 2020. Metode analisis data dan pengujian hipotesis menggunakan analisis jalur dengan menggunkan data panel. Hasil penelitian ini menunjukkan bahwa corporate governance yang diproksikan dengan Dewan Komisaris, Dewan Komisaris Independen, Dewan Direksi dan Dewan Pengawas Syariah tidak berpengaruh terhadap kinerja keuangan dan non performing financing. Artinya semakin tinggi tidaknya corporate governance tidak berpengaruh terhadap kinerja keuangan maupun non performing financing. Dalam penelitian ini juga ditemukan bahwa non performing financing berpengaruh terhadap kinerja keuangan. Apabila non performing financing menurun maka kinerja keuangan akan mengalami peningkatan. Selain itu non performing financing dalam penelitian ini tidak dapat menjadi variabel intervening untuk corporate governance.
\end{abstract}

\section{Kata Kunci : DK DKI; DD; DPS; Kinerja Keuangan; Non Performing Financing}




\section{PENDAHULUAN}

Seiring waktu, persaingan antar bank baik sesama bank syariah maupun bank konvensional semakin ketat. Selain itu, banyak hal tidak terduga lainnya yang dapat memengaruhi perkembangan bank syariah, seperti pandemic COVID 19 yang melanda dunia saat ini dan menyebabkan kondisi perekonomian global menurun. Untuk memulihkan kembali kondisi perekonomian tersebut, peranan perbankan termasuk bank syariah sangat dibutuhkan. Hal tersebut dijelaskan oleh wakil presiden Republik Indonesia bapak Ma'ruf Amin, “ini merupakan momen tepat bagi bank syariah dan juga lembaga keuangan syariah untuk berperan melakukan upaya pemulihan sehingga perlu disiapkan program yang lebih realistis" (Amin, pada Kompas.com, 10 juni 2020).

Untuk mencapai tujuan yang diharapkan perusahaan, tentunya dibutuhkan kinerja yang baik. Kinerja keuangan menjadi patokan utama untuk mengukur baik tidaknya kinerja perusahaan. Hal tersebut dapat dilihat dari laporan keuangannya. Kinerja keuangan bisa dinilai melalui seberapa nilai asset yang bertambah, umur hutang dalam jangka pendek maupun jangka panjang dan dari umur piutang pelanggan. Indikator yang digunakan untuk mengukur disebut rasio keuangan. Rasio keuangan yang umum digunakan adalah profitabilitas dengan pengukuran return on asset (ROA). ROA mengukur profitabilitas perusahaan secara menyeluruh dengan menunjukan efisiensi asset yang dapat menghasilkan laba. Semakin tinggi profitabilitas menunjukkan bahwa kinerja keuangan semakin baik.

Transaksi ataupun kerja sama yang dilakukan bank syariah dengan nasabahnya tentu saja tidak terlepas dari risiko-risiko yang akan terjadi. Salah satu risiko yang terjadi yaitu risiko pembiayaan atau sering disebut risiko kredit. Risiko kredit merupakan risiko yang sangat berpengaruh pada tingkat pendapatan suatu bank sehingga keberadaannya dianggap sangat menentukan tingkat kestabilan kondisi keuangan suatu perusahaan (Aryani, 2019). Untuk mengidentifikasi risiko tersebut dalam menganalisis maka digunakan rasio NPF (Non performing financing). Risiko akan menimbulkan dampak kerugian terhadap bank syariah apabila tidak dikelola dengan baik. Maka penerapan tata kelola dan manajemen yang baik sangat diperlukan. Pencapaian kinerja keuangan yang baik juga tidak terlepas dari tata kelola dan tanggung jawab dari organ-organ perusahan yang menjalankan kinerjanya dengan baik.

Tata kelola yang baik disebut juga dengan good corporate governance (GCG) Corporate governance merupakan sistem yang mengatur dan mengendalikan perusahaan yang diharapkan dapat memberikan dan meningkatkan nilai perusahaan. GCG muncul sebagai akibat dari masalah keagenan yang timbul, yaitu pemisahan kepentingan antara principal dan 
agent. Organ-organ bank syariah terdiri dari beberapa bagian seperti yang akan digunakan pada penelitian ini yaitu dewan komisaris, dewan direksi, dan dewan pengawas syariah.

Seperti penjelasan yang telah dijelaskan diatas bahwa risiko dapat mempengaruhi kestabilan keuangan atau kinerja keuangan maka diperlukan tata kelola yang baik, hal tersebut sejalan dengan penelitian yang dilakukan oleh Setiawaty (2016) tentang pengaruh GCG terhadap kinerja perbankan dengan manajemen risiko yang diproksikan dengan risiko kredit menyatakan adanya pengaruh langsung dan tidak langsung dari GCG terhadap kinerja melalui risiko kredit. Apabila tata kelola dilaksanakan dengan baik maka dapat meminimalisir risiko yang akan terjadi dan kinerja keuangan akan semakin meningkat.

Kinerja keuangan juga dapat dipengaruhi GCG, hal ini sejalan dengan penelitian Eksandy (2018) tentang pengaruh good corporate governance terhadap kinerja keuangan pada perbankan syariah menyatakan bahwa good corporate governance berpengaruh positif terhadap kinerja keuangan, artinya ketika GCG dilaksanakan dengan baik maka kinerja keuangan akan meningkat. Lain halnya dengan penelitian yang dilakukan Yana dan Sari (2019) tentang pengaruh good corporate governance terhadap kinerja keuangan pada perusahaan BPR kota Padang menyatakan bahwa GCG tidak berpengaruh terhadap kinerja keuangan, artinya baik tidaknya penerapan GCG tidak mempengaruhi kinerja keuangan.

Dari hasil penelitian diatas terlihat bahwa kinerja keuangan dipengaruhi oleh risiko kredit atau risiko pembiayaan dan dipengaruhi GCG. Risiko juga dipengaruhi dengan adanya GCG. Hasil penelitian lain diatas juga terlihat bahwa terdapat beberapa hasil yang menyatakan bahwa kinerja keuangan akan dipengaruhi GCG tetapi ada yang menyatakan tidak. Untuk itu penelitian ini dilakukan dengan tujuan untuk menguji corporate governance terhadap kinerja keuangan dengan non performing financing sebagai variabel intervening apakah ada pengaruhnya secara langsung maupun tidak langsung.

Beberapa penelitian mengenai pengaruh dewan komisaris, dewan komisaris independen, dewan direksi dan dewan pengawas syariah terhadap kinerja keuangan dan non performing financing telah dilakukan beberapa peneliti dan menemukan hasil adanya pengaruh, seperti hasil penelitian yang dilakukan oleh Anita et al. (2019), Suwarno dan Muthohar (2018), Rahman dan Safitrie (2018), dan Widiastuty (2018). Para peneliti tersebut menyimpulkan bahwa terdapat pengaruh antara dewan komisaris, dewan komisaris independen, dewan direksi dan dewan pengawas syariah terhadap kinerja keuangan ataupun terhadap non performing financing.

Pengaruh antara corporate governance terhadap kinerja keuangan dengan non performing financing sebagai variabel intervening juga terdapat beberapa peneliti yang telah 
meneliti dan menemukan hasil bahwa corporate governance berpengaruh terhadap kinerja keuangan melalui non performing financing, seperti hasil penelitianyang dilakukan oleh Setiawaty (2016), Aryani (2019), dan Budiman (2016). Hal tersebut berarti bahwa corporate governance mempunyai pengaruh terhadap non performing financing dan non performing financing berpengaruh terhadap kinerja keuangan. Apabila corporate governance dilaksanakan dengan baik akan mampu mengurangi non performing financing dan dengan berkurangnya non performing financing tersebut akan meningkatkan kinerja keuangan.

\section{Teori Keagenan (Agency Theory)}

Corporate governance muncul didasarkan pada teori keagenan yang mengharapkan adanya keterbukaan antara pihak prinsipal dan agen. Prinsipal merupakan pemilik perusahaan dan agen merupakan pihak yang mengelola perusahaan. Pihak prinsipal akan mencari informasi, memberikan insentif untuk memastikan tugas dan tanggungjawab pihak agen terhadap perusahaan. Sebagai pihak agen atau pengelola perusahaan harus mengungkapkan informasi terkait perusahaan terhadap pemilik perusahaan, namun terkadang informasi yang disampaikan tersebut tidak sesuai dengan keadaan yang sebenarnya terjadi di perusahaan sehingga akan menimbulkan permasalah. Agency theory muncul berkaitan dengan penyelesaian permasalahan tersebut. Untuk mengurangi konflik keagenan dapat diterapkan good corporate governance.

\section{Good Corporate Governance}

Menurut Forum For Corporate Governance in Indonesia (FGCI) dalam Setiawaty (2016), corporate governance adalah seperangkat peraturan yang menetapkan hubungan antara pemegang saham, pengurus, pihak kreditur, pemerintah, karyawan, serta para pemegang kepentingan intern dan ekstern lainnya sehubungan dengan hak-hak dan kewajiban mereka, atau dengan kata lain sistem yang mengarahkan dan mengendalikan perusahaan (didukung oleh penelitian dari Sukariana dan Darma, 2015 dan Widiatmika dan Darma, 2018).

Tata kelola yang dijalankan dengan baik akan mampu mempertahankan ketahanan perusahaan dan mampu mengurangi risiko-risiko yang akan terjadi. prinsip-prinsip Good Corporate Governance berdasarkan PBI No.8/4/2006 yang telah diperbarui dengan PBI No.8/14/2006 , yaitu: 1) Transparansi, Transparansi bermakna adanya pengungkapan yang akurat dan tepat waktu tentang seluruh hal yang material atas perusahaan, termasuk kondisi keuangan, kinerja, kepemilikan, dan tata kelola perusahaan, 2) akuntabilitas, praktik pengelolaan bank syariah harus benar-benar dijalankan berdasarkan prinsip syariah, 3) 
pertanggungjawaban, prinsip ini menekankan pada kepentingan para pemangku kepentingan (stakeholders) bank syariah, seperti karyawan, nasabah, konsumen, masyarakat, dan lingkungan sekitar, serta pemerintah selaku regulator. Bank syariah diharapkan selalu memelihara kesinambungan nilai tambah tersebut, 4) profesionalitas, bank syariah harus mengedepankan profesionalisme dan keunggulan layanan (service exellence) kepada nasabah, dan 5) berkeadilan, bank syariah perlu mewujudkan prinsip pengelolaan yang berkeadilan sosial, ekonomi, dan distribusi kekayaan.

\section{Dewan Komisaris}

Dewan Komisaris merupakan organ perusahaan yang bertugas sebagai pengawas manajemen dalam pengelolaan perusahaan dan juga pemberi nasihat kepada dewan direksi. Ukuran Dewan Komisaris merupakan salah satu karakteristik dewan yang terkandung dalam informasi akuntansi. Dewan Komisaris juga merupakan dewan terpenting dalam Good Corporate Governance karena dengan fungsinya sebagai pengawas mampu mempengaruhi setiap manajemen menjadi berkualitas dan berjalan sesuai tujuan. Pengendali dilakukan dalam bentuk memberi petunjuk dan pengarahan tugas dewan direksi. Pembinaan dilakukan untuk meningkatkan kualitas.

\section{Dewan Komisaris Independen}

Dewan Komisaris Independen merupakan organ dewan komisaris yang tidak memiliki hubungan keuangan, kepengurusan dan kepemilikan saham pada bank sehingga mendukung untuk bertindak independen. Dewan komisaris independen ini akan terbagi menjadi tiga komite, yaitu komite pemantau risiko, komite audit dan komite remunerasi. Komite pemantau risiko memiliki tugas dan tanggung jawab melakukan evaluasi terhadap kebijakan manajemen risiko, melakukan evaluasi kebijakan manajemen risiko sesuai dengan pelaksanaan kebijakan yang telah dilakukan, dan melakukan evaluasi kinerja komite manajemen risiko, guna memberikan rekomendasi kepada dewan komisaris. Komite audit bertugas dan bertanggung jawab melakukan evaluasi terhadap pihak intern, dan melakukan koordinasi dengan kantor akuntan publik dalam rangka pelaksanaan aktivitas. Komite remunerasi bertugas melakukan evaluasi kebijakan remunerasi, melakukan evaluasi kebijakan remunerasi terhadap pelaksanaan kebijakan yang telah dilakukan, dan memberikan rekomendasi kepada dewan komisaris mengenai remunerasi bagi pegawai secara keseluruhan. 


\section{Dewan Direksi}

Dewan Direksi adalah sebagaimana yang dimaksud dalam Undang-Undang Nomor 40 tahun 2007 tentang perseroan terbatas yaitu organ yang berwenang dan bertanggung jawab penuh atas pengurusan perseroan dengan maksud dan tujuan sesuai dengan perseroan. Dewan direksi mempertanggung jawabkan pelaksanaan tugasnya pada pemegang saham melalui rapat umum pemegang saham. Dewan direksi wajib mmelaksanakan tugasnya sesuai dengan prinsipprinsip kinerjanya, harus menyajikan data dan informasi secara akurat dan tepat waktu.

\section{Dewan Pengawas Syariah}

Dewan Pengawas Syariah adalah dewan yang bertugas mengawasi kegiatan atau aktivitas bank sesuai dengan prinsip syariah. Dewan pengawas syariah wajib melaksanakan tugaasnya sesuai dengan prinsip Good Corporate Governance. Proses pengambilan keputusan dalam kinerja dewan ini dilaksanakan secara musyawarah mufakat.

Tugas dan tanggung jawab dewan pengawas syariah yaitu menilai dan memastikan dalam operasional bank berjalan sesuai prinsip syariah, mengawasi pengembangan produk baru pada bank agar sesuai dengan prinsip syariah, meminta fatwa baru kepada Dewan Syariah Nasional - Majelis Ulama Indonesia untuk produk baru yang belum ada fatwanya, dan melakukan review atas pemenuhan prinsip syariah dalam penghimpunan dana, penyaluran dana atau pelayanan jasa lainnya.

\section{Kinerja Keuangan}

Kinerja keuangan merupakan cerminan suatu keberhasilan perusahaan, keberhasilan dalam mengelola dan mengalokasikan sumber dayanya. Untuk mengetahui keberhasilan suatu perusahaan perlu diadakan penilaian dan pengukuran kinerja perusahaan dari tiap tahunnya. Penilaian kesehatan bank telah diatur dalam peraturan Otoritas Jasa Keuangan. Penilaian kinerja bank syariah harus dilakukan secara hati-hati dan sesuai dengan prinsip syariah. Penilaian tingkat kesehatan dilakukan sekurang-kurangnya setiap semester untuk posisi akhir bulan Juni dan Desember.

Menurut Peraturan Otoritas Jasa Keuangan nomor 8/POJK.03/2014, penilaian tingkat kesehatan mencangkup penilaian terhadap faktor-faktor yaitu 1) Profil risiko (risk profile), penilaian ini menyangkut penilaian terhadap risiko interen dan kualitas penerapan manajemen risiko dalam operasional, 2) good Corporate Governance, penilaian ini menyangkut pada penilaian terhadap pelaksanaan prinsip-prinsip dan manajemen tata kelola perusahaan, 3) 
rentabilitas (earnings), penilaian terhadap kinerja rentabilitas, sumber, dan stabilitas rentabilitas, dan 4) permodalan (capital), penilaian permodalan ini meliputi penilaian terhadap tingkat kecukupan modal dan pengelolaannya.

Dalam penelitian ini menggunakan Rasio Profitabilitas dan alat analisisnya Return On Asset (ROA). Perhitungan ROA diperoleh dari pembagian laba sebelum pajak dengan total aset. Semakin tinggi ROA maka kinerja perusahaan semakin meningkat.

\section{Non Performing Financing (NPF)}

Non Performing Financing sering dikenal dengan risiko pembiayaan. Non Performing Financing sama dengan Non Performing Loan dalam bank konvensional, memiliki arti sebagai risiko yang muncul sebagai akibat dari kegagalan pihak ketiga dalam memenuhi kewajibannya pada jumlah dan waktu yang telah disepakati (Hnggraeni, 2019). Pihak ketiga yang menjadi sumber dari risiko kredit pada bank syariah mencakup obligor, supplier, ataupun mudharib dan mitra dalam akad musyarakah. Pihak ketiga tersebut dinyatakan gagal bayar ketika mereka tidak mampu membayar kewajibannya pada waktu yang telah ditentukan. Semakin tinggi risiko akan menyebabkan biaya yang semakin meningkat sehingga bank akan mengalami kerugian.

\section{Kerangka penelitian}

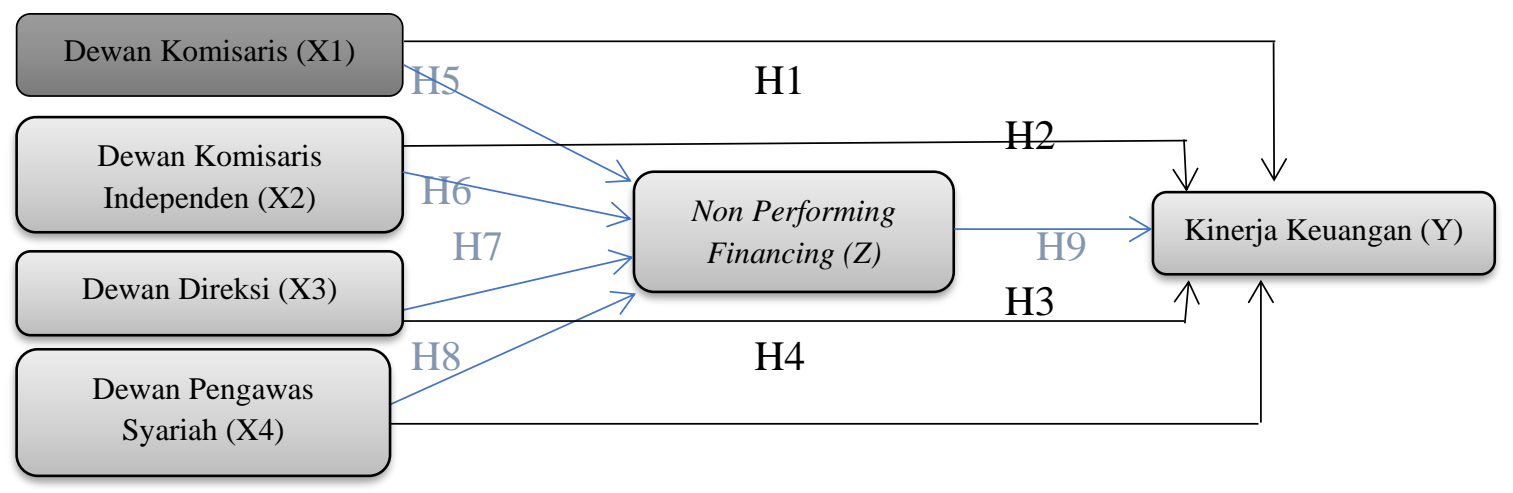

\section{Hipotesis}

$\mathrm{H}_{1}$ : Dewan Komisaris berpengaruh positif signifikan terhadap Kinerja Keuangan

$\mathrm{H}_{2}$ : Dewan Komisaris Independen berpengaruh positif signifikan terhadap Kinerja Keuangan

$\mathrm{H}_{3}$ : Dewan Direksi berpengaruh positif signifikan terhadap Kinerja Keuangan

$\mathrm{H}_{4}$ : Dewan Pengawas Syariah berpengaruh positif signifikan terhadap Kinerja Keuangan

$\mathrm{H}_{5}$ : Dewan Komisaris berpengaruh negatif dan signifikan terhadap NPF

$\mathrm{H}_{6}$ : Dewan Komisaris Independen berpengaruh negatif dan signifikan terhadap NPF

$\mathrm{H}_{7}$ : Dewan Direksi berpengaruh negatif dan signifikan terhadap NPF

$\mathrm{H}_{8}$ : Dewan Pengawas Syariah berpengaruh negatif dan signifikan terhadap NPF 
$\mathrm{H}_{9}$ : NPF berpengaruh negatif dan signifikan terhadap Kinerja Keuangan

$\mathrm{H}_{10}$ : NPF mampu memediasi pengaruh antara Dewan Komisaris terhadap Kinerja Keuangan

$\mathrm{H}_{11}$ : NPF mampu memediasi pengaruh antara Dewan Komisaris Independen terhadap Kinerja

Keuangan

$\mathrm{H}_{12}$ : NPF mampu memediasi pengaruh antara Dewan Direksi terhadap Kinerja Keuangan

$\mathrm{H}_{13}$ : NPF mampu memediasi pengaruh antara Dewan Pengawas Syariah terhadap Kinerja Keuangan.

\section{METODE PENELITIAN}

Populasi dalam penelitian ini adalah seluruh bank umum syariah di Indonesia tahun 2017-2020 yang berjumlah 14. Pengambilan sampel dilakukan dengan teknik purposive sampling atau dengan kriteria tertentu. Kriteria pengambilan sampel dalam penelitian ini adalah sebagai berikut:

a. Lembaga perbankan yang termasuk Bank Umum Syariah

b. Bank Umum Syariah yang terdaftar di OJK periode tahun 2017-2020

c. Bank Umum Syariah yang menyajikan laporan keuangan triwulan dan telah dipublikasikan di website masing-masing bank periode 2017-2020

d. Data yang dipublikasikan memiliki kelengkapan data yang diperlukan untuk penelitian ini

e. Bank Umum Syariah yang melakukan relaksasi kredit periode 2020

Berdasarkan kriteria tersebut, diperoleh sampel sebanyak 8 bank umum syariah. Teknik pengumpulan dan pencatatan data diperoleh melalui laporan triwulan masing-masing bank syariah dimulai dari triwulan pertama tahun 2017 sampai triwulan kedua tahun 2020. Variabel dalam penelitian ini terdiri dari variabel independen, variabel dependen dan variabel intervening.

Variabel independen yang digunakan dalam penelitian ini adalah dewan komisaris (DK), dewan komisaris independen (DKI), dewan direksi (DD) dan dewan pengawas syariah (DPS). Dewan komisaris diukur menggunakan ukuran yaitu jumlah seluruh dewan komisaris. Dewan komisaris independen diukur menggunakan ukuran yaitu jumlah dewan komisaris independen dibagi dengan jumlah seluruh dewan komisaris. Dewan direksi diukur menggunakan ukuran yaitu jumlah seluruh dewan direksi. Dewan pengawas syariah diukur menggunakan ukuran yaitu jumlah seluruh dewan pengawas syariah.

Variabel dependen yang digunakan dalam penelitian ini adalah kinerja keuangan yang diukur menggunakan rasio profitabilitas. Alat ukurnya menggunakan return on asset (ROA). ROA diperoleh dari perbandingan laba sebelum pajak dibagi dengan rata-rata total asset. 
Variabel intervening yang digunakan dalam penelitian ini adalah non performing financing (NPF). NPF terjadi karena pihak ketiga atau pihak yang melakukan pembiayaan gagal memenuhi kewajibannya. NPF diperoleh dari jumlah pembiayaan bermasalah dibagi dengan total pembiayaan.

Metode analisa data yang digunakan untuk mengetahui pengaruh variabel independen terhadap variabel dependen dengan variabel intervening dalam penelitian ini adalah dengan analisis regresi berganda. Sebelum melakukan uji regresi, terlebih dahulu dilakukan uji asumsi klasik dengan tujuan untuk mengetahui apakah data dalam penelitian memenuhi asumsi-asumsi dasar. Sebelum melakukan uji asumsi klasik terlebih dahulu dilakukan uji untuk menetapkan model. Pengujian yang dilakukan dalam uji asumsi klasik adalah uji normalitas, uji multikolinearitas, uji heteroskedastisitas dan uji autokorelasi. Penelitian ini menggunakan variabel intervening, maka diperlukan adanya uji path analysis.

Berikut rumus persamaan path analysis dalam penelitian ini:

$\mathrm{NPF}=\beta 0+\beta 1 . \mathrm{X} 1+\beta 2 . \mathrm{X} 2+\beta 3 . \mathrm{X} 3+\beta 4 . \mathrm{X} 4+£$.

$Y=\beta 0+\beta 1 . X 1+\beta 2 . X 2+\beta 3 . X 3+\beta 4 . X 4+\beta 5 . Z 1+£ \ldots .$.

Dimana:

Y : Kinerja keuangan

$\beta 0 \quad$ : Konstanta dari persamaan regresi

$\beta 1-\beta 4$ : Konstanta dari variabel independen

$\beta 5 \quad$ : Konstanta dari variabel intervening

X1 : Dewan Komisaris
X2 : Dewan Komisaris Independen

X3 : Dewan Direksi

X4 : Dewan Pengawas Syariah

$\mathrm{Z} 1 \quad$ : Non Performing Financing

$£ \quad$ : Variabel residual

\section{HASIL PENELITIAN DAN PEMBAHASAN}

\section{Uji Asumsi Klasik}

Sebelum melakukan uji asumsi klasik, terlebih dahulu menentukan model apa yang tepat digunakan dalam proses pengujian data selanjutnya.

Tabel 4.3 Hasil uji Ketepatan Model

\begin{tabular}{|l|l|}
\hline & Probabilitas \\
\hline Chow Test & 0.0000 \\
\hline Hausman Test & 0.6340 \\
\hline Lagrange Multiplier Test & 0.0000 \\
\hline
\end{tabular}

Sumber: Data diolah eviews 9

Pengujian untuk menentukan metode pengujian data yang pertama dilakukan dengan uji chow, dimana dalam uji ini apabila nilai probabilitasnya $<0,05$ maka metode terbaik yang 
digunakan adalah fixed effect. Pada tabel 4.3 menunjukkan dalam Chow Test nilai probabilitasnya 0,0000. Tahap selanjutnya dilakukan uji Hausman, dimana dalam uji ini apabila nilai probabilitasnya $>0,05$ maka metode terbaik yang digunakan adalah random effect. Dari kedua uji tersebut belum ditemukan adanya metode terbaik yang bisa digunakan dalam penelitian, dengan begitu perlu adanya uji lanjut yaitu uji Lagrange Multiplier test. Dalam uji LM apabila probabilitasnya $<0,05$ maka metode yang digunakan adalah random effect. Pada tabel 4.3 dalam uji Chow menunjukkan nilai probabilitas 0,0000. Dalam uji Hausman menunjukkan nilai probabilitas 0,6340. Dalam uji LM menunjukkan nilai probabilitas 0,0000. Maka dalam penelitian ini metode terbaik yang dapat digunakan dalam pengujian selanjutnya yaitu random effect.

\section{Uji Normalitas}

Alat yang digunakan untuk uji normalitas yaitu Uji Jarque-Bera.Variabel yang dapat memenuhi syarat uji normalitas atau dikatakan normal apabila nilai Jarque-Bera probabilitasnya $>0,05$.

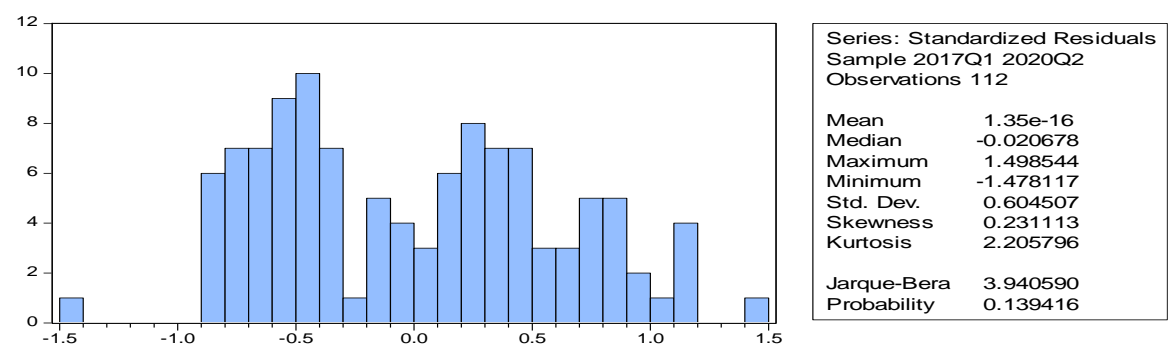

Gambar 4.1 Hasil Uji Normalitas ROA

Dari gambar 4.1 menunjukkan hasil uji normalitas dengan nilai Jarque-Bera probabilitasnya dari variabel independen dan dependen sebesar 0,139416. Data dinyatakan telah memenuhi syarat uji normalitas yaitu mempunyai nilai Jarque-Bera probabilitas $>0,05$, maka data dikatakan berdistribusi normal.

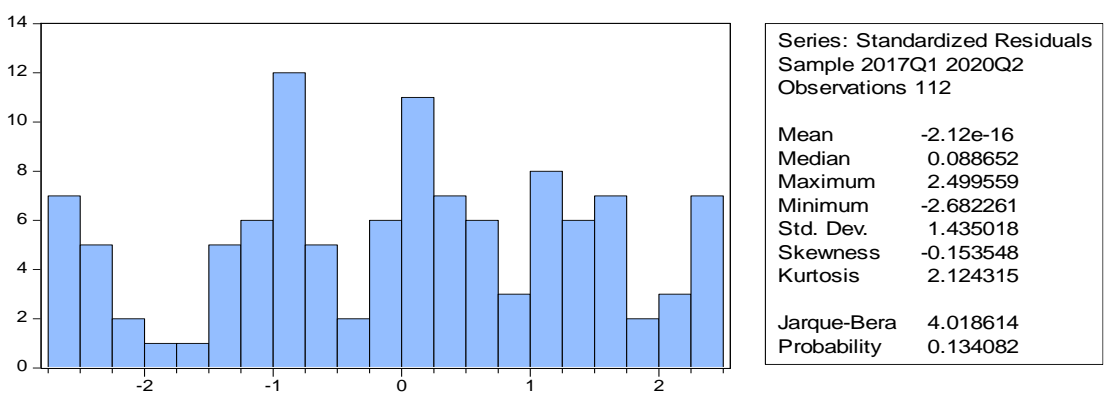

Gambar 4.2 Hasil Uji Normalitas NPF 
Dari gambar 4.2 menunjukkan hasil uji normalitas dengan nilai Jarque-Bera probabilitasnya dari variabel independen dan dependen sebesar 0,134082 . Data dinyatakan telah memenuhi syarat uji normalitas yaitu mempunyai nilai Jarque-Bera probabilitas $>0,05$, maka data dikatakan berdistribusi normal.

\section{Uji Multikolinearitas}

Tabel 4.4 Hasil Uji Multikolinearitas

\begin{tabular}{lllll} 
& DK & DKI & DD & DPS \\
\hline \hline DK & 0.547114 & 0.016004 & 0.563776 & 0.123007 \\
DKI & 0.016004 & 0.032662 & 0.052168 & 0.015780 \\
DD & 0.563776 & 0.052168 & 1.584184 & 0.376276 \\
DPS & 0.123007 & 0.015780 & 0.376276 & 0.198900
\end{tabular}

Dalam uji ini apabila koefisien antar variabel bebas melebihi 0,8 maka data dikatakan multikolinearitas. Hasil uji multikolinearitas pada tabel 4.5 menunjukkan nilai hubungan antar variabel bebas tidak lebih dari 0,8 maka dalam pengujian ini tidak mengalami multikolinearitas. Dengan kata lain tidak terjadi masalah dalam data dan data dapat dikatakan aman untuk dilakukan uji-uji selanjutnya.

\section{Uji Heteroskedastisitas}

Tabel 4.5 Hasil Uji Heteroskedastisitas

\begin{tabular}{|c|c|c|c|c|}
\hline \multicolumn{5}{|c|}{$\begin{array}{l}\text { Dependent Variable: NRESABS } \\
\text { Method: Panel EGLS (Cross-section random effects) } \\
\text { Date: 10/15/20 Time: 07:20 } \\
\text { Sample (adjusted): } 2017 \mathrm{Q} 2020 \mathrm{2} 2 \\
\text { Periods included: } 13 \\
\text { Cross-sections included: } 8 \\
\text { Total panel (unbalanced) observations: } 112 \\
\text { Swamy and Arora estimator of component variances }\end{array}$} \\
\hline Variable & Coefficient & Std. Error & t-Statistic & Prob. \\
\hline $\mathrm{C}$ & -0.604594 & 0.350611 & -1.724402 & 0.0880 \\
\hline NDK & 0.765229 & 0.404054 & 1.893878 & 0.0614 \\
\hline NDKI & 0.304592 & 0.239228 & 1.273230 & 0.2062 \\
\hline NDD & -0.094401 & 0.322594 & -0.292632 & 0.7705 \\
\hline NDPS & 0.193206 & 0.292514 & 0.660501 & 0.5106 \\
\hline NPF & -0.039883 & 0.040676 & -0.980500 & 0.3294 \\
\hline
\end{tabular}

Sumber: Data diolah eviews 9

Tabel 4.5 menunjukkan hasil dari uji heteroskedastisitas, dimana uji ini menggunakan uji Glejser. Apabila nilai probabilitasnya kurang dari 0,05 maka terjadi heteroskedastisitas. 
Tabel di atas menunjukkan bahwa nilai probabilitasnya dari masing-masing variabel melebihi dari nilai 0,05 maka dapat disimpulkan bahwa dalam uji ini tidak terjadi heteroskedastisitas.

\section{Uji Autokorelasi}

Tabel 4.6 Hasil Uji Autokorelasi ROA

Dependent Variable: NROA

Method: Panel EGLS (Cross-section random effects)

Date: $10 / 05 / 20$ Time: $16: 28$

Sample (adjusted): 2017Q2 2020Q2

Periods included: 13

Cross-sections included: 8

Total panel (unbalanced) observations: 112

Swamy and Arora estimator of component variances

\begin{tabular}{llll}
\hline \hline R-squared & 0.144482 & Mean dependent var & -0.109549 \\
Adjusted R-squared & 0.096419 & S.D. dependent var & 0.525289 \\
S.E. of regression & 0.498793 & Sum squared resid & 22.14268 \\
F-statistic & 3.006104 & Durbin-Watson stat & 1.781089 \\
Prob(F-statistic) & 0.014878 & & \\
\hline \hline
\end{tabular}

Sumber: Data diolah eviews 9

Hasil uji autokorelasi pada tabel 4.6 menunjukkan bahwa jumlah sampel $112(n=112)$ dan jumlah variabel sebesar $4(\mathrm{k}=4)$, nilai Durbin Watson (DW) sebesar 1,781089. Besarnya DW pada tabel untuk dl (batas bawah) yaitu 1,6187 dan DW pada tabel untuk du (batas atas) yaitu 1,7664 . Sehingga besarnya nilai $4-d l=2,3813$ dan nilai $4-d u=2,2336$. Dapat disimpulkan bahwa tidak terjadi autokorelasi.

Tabel 4.7 Hasil Uji Autokorelasi NPF

Dependent Variable: NNPF

Method: Panel EGLS (Cross-section random effects)

Date: $10 / 05 / 20$ Time: $16: 25$

Sample (adjusted): 2017Q2 2020Q2

Periods included: 13

Cross-sections included: 8

Total panel (unbalanced) observations: 112

Swamy and Arora estimator of component variances

\begin{tabular}{llll}
\hline \hline R-squared & 0.023563 & Mean dependent var & 0.059082 \\
Adjusted R-squared & -0.018891 & S.D. dependent var & 0.308724 \\
S.E. of regression & 0.311235 & Sum squared resid & 8.911769 \\
F-statistic & 0.555033 & Durbin-Watson stat & 1.884538 \\
Prob(F-statistic) & 0.695838 & & \\
\hline \hline
\end{tabular}

Sumber: Data diolah eviews 9

Hasil uji autokorelasi pada tabel 4.7menunjukkan bahwa jumlah sampel $112(n=112)$ dan jumlah variabel sebesar $4(\mathrm{k}=4)$, nilai Durbin Watson (DW) sebesar 1,884538. Besarnya DW pada tabel untuk dl (batas bawah) yaitu 1,6187 dan DW pada tabel untuk du (batas atas) 
yaitu 1,7664 . Sehingga besarnya nilai $4-d l=2,3813$ dan nilai $4-d u=2,2336$. Dapat disimpulkan bahwa tidak terjadi otokorelasi.

\section{Uji Regresi}

\section{Tabel 4.8 Hasil Uji Regresi ROA}

Method: Panel EGLS (Cross-section random effects)

Date: 10/05/20 Time: 16:28

Sample (adjusted): 2017Q2 2020Q2

Periods included: 13

Cross-sections included: 8

Total panel (unbalanced) observations: 112

Swamy and Arora estimator of component variances

\begin{tabular}{lllll}
\hline \hline Variable & Coefficient & Std. Error & t-Statistic & Prob. \\
\hline \hline C & 0.068372 & 0.626091 & 0.109205 & 0.9133 \\
NDK & -0.112258 & 0.665902 & -0.168581 & 0.8665 \\
NDKI & -0.144099 & 0.380333 & -0.378875 & 0.7057 \\
NDD & 0.379628 & 0.507631 & 0.747844 & 0.4565 \\
NDPS & -0.329486 & 0.444162 & -0.741816 & 0.4602 \\
NPF & -0.260288 & 0.071328 & -3.649180 & 0.0004 \\
\hline \hline
\end{tabular}

\begin{tabular}{|c|c|c|c|}
\hline \multicolumn{2}{|c|}{ Effects Specification } & S.D. & Rho \\
\hline $\begin{array}{l}\text { Cross-section randon } \\
\text { Idiosyncratic random }\end{array}$ & & $\begin{array}{l}0.618052 \\
0.506682\end{array}$ & $\begin{array}{l}0.5981 \\
0.4019\end{array}$ \\
\hline & Weighted Statis & & \\
\hline $\begin{array}{l}\text { R-squared } \\
\text { Adjusted R-squared } \\
\text { S.E. of regression } \\
\text { F-statistic } \\
\text { Prob(F-statistic) }\end{array}$ & $\begin{array}{l}0.144482 \\
0.096419 \\
0.498793 \\
3.006104 \\
0.014878\end{array}$ & $\begin{array}{l}\text { Mean dependent var } \\
\text { S.D. dependent var } \\
\text { Sum squared resid } \\
\text { Durbin-Watson stat }\end{array}$ & $\begin{array}{l}-0.109549 \\
0.525289 \\
22.14268 \\
1.781089\end{array}$ \\
\hline
\end{tabular}

Dari hasil pengujian regresi di atas, maka persamaan model regresi yang digunakan sebagai berikut:

$\mathrm{ROA}=0,068372-0,112258(\mathrm{DK})-0,144099(\mathrm{DKI})+0,379628(\mathrm{DD})-0,329486(\mathrm{DPS})-$ $0,260288(\mathrm{NPF})$

\section{Koefisien Determinasi $\mathbf{R}^{2}$}

$\mathrm{R}^{2}$ mengukur kemampuan model dalam menerangkan pengaruh variasi variabel dependen. Dalam tabel 4.9 menunjukkan nilai R-squared sebesar 0,14. Hal tersebut menunjukkan tingkat pengaruh variabel independen terhadap variabel dependen sebesar $14 \%$, sedangkan sisanya sebesar $86 \%$ (100\%-14\%) dijelaskan variabel lain di luar model regresi ini. 


\section{Uji T}

Dari hasil pengujian di atas variabel dewan komisaris memiliki nilai probabilitas sebesar 0,8665. Nilai probabilitas tersebut lebih besar dari 0,05 dan mempunyai koefisien negatif, maka dapat dikatakan bahwa secara parsial dewan komisaris berpengaruh negatif dan tidak signifikan terhadap ROA. Variabel dewan komisaris independen memiliki nilai probabilitas sebesar 0,7057 . Nilai probabilitas tersebut lebih besar dari 0,05 dan mempunyai koefisien negatif, maka dapat dikatakan bahwa secara parsial dewan komisaris independen berpengaruh negatif dan tidak signifikan terhadap ROA. Variabel dewan direksi memiliki nilai probabilitas sebesar 0,4565 . Nilai probabilitas tersebut lebih besar dari 0,05 dan mempunyai koefisien positif, maka dapat dikatakan bahwa secara parsial dewan direksi berpengaruh positif dan tidak signifikan terhadap ROA. Variabel dewan pengawas syariah memiliki nilai probabilitas sebesar 0,4602 . Nilai probabilitas tersebut lebih besar dari 0,05 dan mempunyai koefisien negatif, maka dapat dikatakan bahwa secara parsial dewan pengawas syariah berpengaruh negatif dan tidak signifikan terhadap ROA. Variabel NPF memiliki nilai probabilitas sebesar 0,0004 . Nilai probabilitas tersebut lebih kecil dari 0,05 dan mempunyai koefisien negatif, maka dapat dikatakan bahwa secara parsial NPF berpengaruh negatif dan signifikan terhadap ROA.

\section{Uji F}

Uji F mununjukkan pengaruh secara bersama-sama variabel independen yang dimasukan ke dalam model terhadap variabel dependen. Pengujian ini dapat diketahui dengan melihat nilai prob(F-statistic). Penelitian ini mempunyai nilai prob(F-statistic) sebesar 0,014878 dengan probabilitas lebih kecil dari 0,05, sehingga dapat disimpulkan bahwa variabel DK, DKI, DD, DPS, NPF mampu berpengaruh secara bersama-sama terhadap ROA.

\section{Tabel 4.9 Hasil Uji Regresi NPF}

Dependent Variable: NNPF

Method: Panel EGLS (Cross-section random effects)

Date: 10/05/20 Time: 16:25

Sample (adjusted): 2017Q2 2020Q2

Periods included: 13

Cross-sections included: 8

Total panel (unbalanced) observations: 112

Swamy and Arora estimator of component variances

\begin{tabular}{lllll}
\hline \hline Variable & Coefficient & Std. Error & t-Statistic & Prob. \\
\hline \hline C & 0.432594 & 0.372604 & 1.161002 & 0.2486 \\
NDK & -0.503707 & 0.407467 & -1.236191 & 0.2195 \\
NDKI & -0.142754 & 0.237071 & -0.602157 & 0.5486 \\
NDD & 0.262677 & 0.315368 & 0.832924 & 0.4070
\end{tabular}




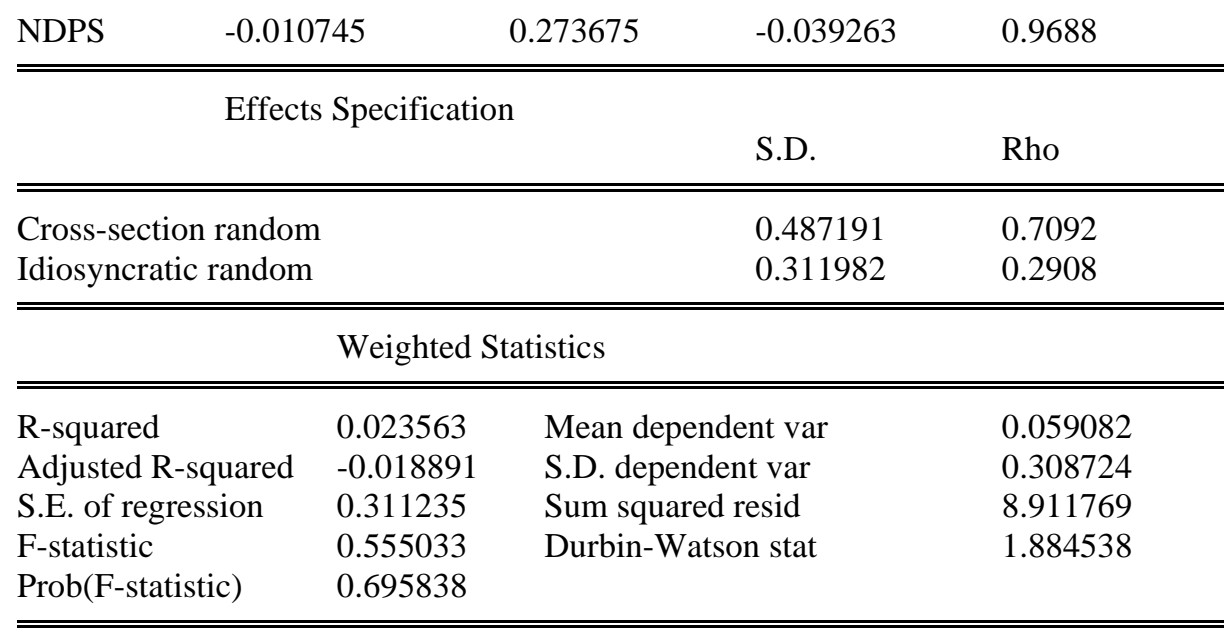

Sumber: Data diolah eviews 9

Dari hasil pengujian regresi di atas, maka persamaan model regresi yang digunakan sebagai berikut:

$\mathrm{ROA}=0,432594-0,503707(\mathrm{DK})-0,142754(\mathrm{DKI})+0,262677$ (DD) $-0,010745$ (DPS)

\section{Koefisien Determinasi $\mathbf{R}^{2}$}

$\mathrm{R}^{2}$ mengukur kemampuan model dalam menerangkan pengaruh variasi variabel dependen. Dalam tabel 4.9 menunjukkan nilai R-squared sebesar 0,02. Hal tersebut menunjukkan tingkat pengaruh variabel independen terhadap variabel dependen sebesar $2 \%$, sedangkan sisanya sebesar 98\% (100\%-98\%) dijelaskan variabel lain di luar model regresi ini.

\section{Uji T}

Dari hasil pengujian di atas variabel dewan komisaris memiliki nilai probabilitas sebesar 0,2195. Nilai probabilitas tersebut lebih besar dari 0,05 dan mempunyai koefisien negatif, maka dapat dikatakan bahwa secara parsial dewan komisaris berpengaruh negatif dan tidak signifikan terhadap NPF. Variabel dewan komisaris independen memiliki nilai probabilitas sebesar 0,5486 . Nilai probabilitas tersebut lebih besar dari 0,05 dan mempunyai koefisien negatif, maka dapat dikatakan bahwa secara parsial dewan komisaris independen berpengaruh negatif dan tidak signifikan terhadap NPF. Variabel dewan direksi memiliki nilai probabilitas sebesar 0,4070 . Nilai probabilitas tersebut lebih besar dari 0,05 dan mempunyai koefisien positif, maka dapat dikatakan bahwa secara parsial dewan direksi berpengaruh positif dan tidak signifikan terhadap NPF. Variabel dewan pengawas syariah memiliki nilai probabilitas sebesar 0,9688 . Nilai probabilitas tersebut lebih besar dari 0,05 dan mempunyai koefisien negatif, maka dapat dikatakan bahwa secara parsial dewan pengawas syariah berpengaruh negatif dan tidak signifikan terhadap NPF. 


\section{Uji F}

Uji $F$ mununjukkan pengaruh secara bersama-sama variabel independen yang dimasukan ke dalam model terhadap variabel dependen. Pengujian ini dapat diketahui dengan melihat nilai prob(F-statistic). Penelitian ini mempunyai nilai prob(F-statistic) sebesar 0,695838 dengan probabilitas lebih besar dari 0,05, sehingga dapat disimpulkan bahwa variabel DK, DKI, DD, DPS tidak berpengaruh secara bersama-sama terhadap NPF.

\section{Uji Path Analysis}

Uji path analysis digunakan untuk mengetahui pengaruh variabel independen (DK, DKI, DD, DPS) terhadap variabel dependen (ROA) melalui variabel penghubung atau variabel intervening (NPF). Hasil pengujian regresi dapat digunakan dalam proses pengujian selanjutnya yaitu uji t satistik atau t hitung untuk mengetahui apakah ada pengaruh mediasi atau tidak dalam penelitian ini. Sebelum perhitungan t harus diketahui terlebih dahulu standar error koefisiensinya. Berikut perhitungannya:

Tabel 4.11 Tabel Uji Path Analysis

\begin{tabular}{|l|l|l|l|l|l|}
\hline Variabel & $\begin{array}{l}\text { P1 } \\
(\mathrm{X}-\mathrm{Y})\end{array}$ & $\begin{array}{l}\text { P2 } \\
(\mathrm{X}-\mathrm{Z})\end{array}$ & $\begin{array}{l}\text { P3 } \\
(\mathrm{Z}-\mathrm{Y})\end{array}$ & $\begin{array}{l}\text { SP2 } \\
(\mathrm{X}-\mathrm{Z})\end{array}$ & $\begin{array}{l}\text { SP3 } \\
(\mathrm{Z}-\mathrm{Y})\end{array}$ \\
\hline DK & -0.112258 & -0.503707 & -0.260288 & 0.407467 & 0.071328 \\
\hline DKI & -0.144099 & -0.142754 & -0.260288 & 0.237071 & 0.071328 \\
\hline DD & 0.379628 & -0.262677 & -0.260288 & 0.315368 & 0.071328 \\
\hline DPS & -0.329486 & -0.010745 & -0.260288 & 0.273675 & 0.071328 \\
\hline
\end{tabular}

1. DK SP2P3

$$
\begin{aligned}
= & \sqrt{(P 3) 2}(S P 2) 2+(P 2) 2(S P 3) 2+(S P 2) 2(S P 3) 3 \\
= & (-0,260288)^{2} \cdot(0,407467)^{2}+(-0,503707)^{2} \cdot(0,071328)^{2}+(0,407467)^{2} \\
& \cdot(0,071328)^{2}=\sqrt{0,011248}+0,001291+0,000844 \\
= & \sqrt{0,013383}=0,115684
\end{aligned}
$$

2. DKI SP2P3 $=\sqrt{(P 3) 2}(S P 2) 2+(P 2) 2(S P 3) 2+(S P 2) 2(S P 3) 3$

$$
=(-0,260288)^{2} \cdot(0,237071)^{2}+(-0,142754)^{2} \cdot(0,071328)^{2}+(0,237071)^{2}
$$$$
\text { . }(0,071328)^{2}=\sqrt{0,003808}+0,000103+0,000286
$$$$
=\sqrt{0,004197}=0,064784
$$

3. DD SP2P3 $=\sqrt{(P 3) 2}(S P 2) 2+(P 2) 2(S P 3) 2+(S P 2) 2(S P 3) 3$

$=(-0,260288)^{2} \cdot(0,315368)^{2}+(-0,262677)^{2} \cdot(0,071328)^{2}+(0,315368)^{2}$

$$
.(0,071328)^{2}=\sqrt{0,006738}+0,000351+0,000506
$$

$=\sqrt{0,007595}=0,087192$

4. DPS SP2P3 $=\sqrt{(P 3) 2}(S P 2) 2+(P 2) 2(S P 3) 2+(S P 2) 2(S P 3) 3$

$$
=(-0,260288)^{2} \cdot(0,273675)^{2}+(-0,010745)^{2} \cdot(0,071328)^{2}+(0,273675)^{2}
$$$$
.(0,071328)^{2}=\sqrt{0,005074}+5,873986+0,000381
$$

$=\sqrt{5}, 879441=2,424756$ 
Keterangan:

SP2P3 : Standar error koefisiensi

P2 : Koefisiensi regresi pada kolom unstandardized coefficients untuk pengaruh variabel independen terhadap variabel intervening

P3 : Koefisiensi regresi pada kolom unstandardized coefficients untuk pengaruh variabel intervening terhadap variabel dependen

SP2 : Standar error pada kolom unstandardized untuk pengaruh variabel independen terhadap variabel intervening

SP3 : Standar error pada kolom unstandardized untuk pengaruh variabel intervening terhadap variabel dependen

Dari hasil perhitungan SP2P3 di atas, maka nilai t statistik pengaruh mediasi dalam penelitian ini dapat diketahui yaitu sebagai berikut:

t statistik $=\frac{P 2 P 3}{S P 2 P 3}$

1. $\mathrm{t}$ statistik DK $=\frac{(-0,503707) \cdot(-0,260288)}{0,115684}=1,133336$

2. $\mathrm{t}$ statistik DKI $=\frac{(-0,142754) \cdot(-0,260288)}{0,064784}=0,573554$

3. $\mathrm{t}$ statistik DD $\quad=\frac{(-0,262677) \cdot(-0,260288)}{0,087192}=0,784150$

4. $\mathrm{t}$ statistik DPS $\quad=\frac{(-0,010745) \cdot(-0,260288)}{2,424756}=0,001153$

Berdasarkan perhitungan $\mathrm{t}$ statistik di atas, maka dapat ditarik kesimpulan sebagai berikut:

1. Nilai t tabel dengan tingkat signifikansi 0,05 yaitu 1,98137 . Nilai t statistik DK sebesar 1,133336 lebih kecil dari nilai t tabel 1,98137. Hal tersebut menunjukkan bahwa t statistik dari variabel DK tidak signifikan, artinya NPF tidak dapat berperan sebagai variabel intervening dalam pengaruh Dewan Komisaris terhadap kinerja keuangan (ROA).

2. Nilai t tabel dengan tingkat signifikansi 0,05 yaitu 1,98137 . Nilai t statistik DKI sebesar 0,573554 lebih kecil dari nilai t tabel 1,98137. Hal tersebut menunjukkan bahwa t statistik dari variabel DKI tidak signifikan, artinya NPF tidak dapat berperan sebagai variabel intervening dalam pengaruh Dewan Komisaris Independen terhadap kinerja keuangan (ROA).

3. Nilai t tabel dengan tingkat signifikansi 0,05 yaitu 1,98137 . Nilai t statistik DD sebesar 0,784150 lebih kecil dari nilai t tabel 1,98137. Hal tersebut menunjukkan bahwa t statistik dari variabel DD tidak signifikan, artinya NPF tidak dapat berperan sebagai variabel intervening dalam pengaruh Dewan Direksi terhadap kinerja keuangan (ROA).

4. Nilai t tabel dengan tingkat signifikansi 0,05 yaitu 1,98137 . Nilai t statistik DPS sebesar 0,001153 lebih kecil dari nilai t tabel 1,98137. Hal tersebut menunjukkan bahwa t statistik dari variabel DPS tidak signifikan, artinya NPF tidak dapat berperan sebagai variabel intervening dalam pengaruh Dewan Pengawas Syariah terhadap kinerja keuangan (ROA). 


\section{Pembahasan Hasil Analisis}

1. Variabel dewan komisaris mempunyai nilai koefisien ke arah negatif yaitu sebesar 0,112258 dan nilai probabilitas sebesar 0,8665 . Nilai tersebut lebih besar dari nilai alpha 0,05, maka dewan yang diproksikan dengan ukuran dewan komisaris tidak berpengaruh terhadap kinerja keuangan, artinya hipotesis pertama $\left(\mathrm{H}_{1}\right)$ yang menyatakan bahwa dewan komisaris berpengaruh positif signifikan tehadap kinerja keuangan dalam penelitian ini ditolak. Dengan kata lain hasil penelitian ini menyatakan bahwa semakin besar dewan komisaris akan menurunkan kinerja keuangan. Hasil tersebut berbeda dengan hasil penelitian Prasetyo dan Dewayanto (2019), yang menyatakan bahwa ukuran dewan komisaris berpengaruh positif signifikan tehadap kinerja keuangan.

2. Variabel dewan komisaris independen mempunyai nilai koefisien ke arah negatif yaitu sebesar -0,144099 dan nilai probabilitas sebesar 0,7057. Nilai tersebut lebih besar dari nilai alpha 0,05, maka dewan yang diproksikan dengan ukuran dewan komisaris independen tidak berpengaruh terhadap kinerja keuangan, artinya hipotesis $\left(\mathrm{H}_{2}\right)$ yang menyatakan bahwa dewan komisaris independen berpengaruh positif signifikan tehadap kinerja keuangan dalam penelitian ini ditolak. Dengan kata lain hasil penelitian ini menyatakan bahwa semakin besar dewan komisaris independen akan menurunkan kinerja keuangan. Hasil penelitian ini berbeda dengan hasil penelitian Putra (2015) yang menunjukan adanya pengaruh positif signifikan antara dewan komisaris independen terhadap kinerja keuangan.

3. Variabel dewan komisaris direksi mempunyai nilai koefisien ke arah positif yaitu sebesar 0,379486 dan nilai probabilitas sebesar 0,4565. Nilai tersebut lebih besar dari nilai alpha 0,05, maka dewan yang diproksikan dengan ukuran dewan direksi tidak berpengaruh terhadap kinerja keuangan, artinya hipotesis $\left(\mathrm{H}_{3}\right)$ yang menyatakan bahwa dewan direksi berpengaruh positif signifikan tehadap kinerja keuangan dalam penelitian ini ditolak. Dengan kata lain hasil penelitian ini menyatakan bahwa semakin besar dewan direksi akan menurunkan kinerja keuangan. Hasil penelitian ini berbeda dengan hasil penelitian Anita et al. (2019) yang menyatakan bahwa ukuran dewan direksi berpengaruh positif signifikan terhadap kinerja keuangan perusahaan.

4. Variabel dewan pengawas syariah mempunyai nilai koefisien ke arah negatif yaitu sebesar $-0,329486$ dan nilai probabilitas sebesar 0,4602. Nilai tersebut lebih besar dari nilai alpha 0,05, maka dewan yang diproksikan dengan ukuran dewan pengawas syariah tidak berpengaruh terhadap kinerja keuangan, artinya hipotesis $\left(\mathrm{H}_{4}\right)$ yang menyatakan bahwa dewan pengawas syariah berpengaruh positif signifikan tehadap kinerja keuangan dalam penelitian ini ditolak. Dengan kata lain hasil penelitian ini menyatakan bahwa semakin 
besar dewan pengawas syariah akan menurunkan kinerja keuangan. Hasil penelitian ini berbeda dengan hasil penelitian Rahmawati et al. (2017) yang menyatakan bahwa dewan pengawas syariah berpengaruh positif signifikan terhadap kinerja keuangan.

5. Variabel dewan komisaris mempunyai nilai koefisien ke arah negatif yaitu sebesar 0,503707 dan nilai probabilitas sebesar 0,2195. Nilai tersebut lebih besar dari nilai alpha 0,05, maka dewan yang diproksikan dengan ukuran dewan komisaris tidak berpengaruh terhadap NPF, artinya hipotesis $\left(\mathrm{H}_{5}\right)$ yang menyatakan bahwa dewan komisaris berpengaruh negatif signifikan tehadap NPF dalam penelitian ini ditolak. Hasil penelitian ini berbeda dengan hasil penelitian Budiman (2016) yang menunjukan hasil bahwa dewan komisaris bepengaruh negatif signifikan terhadap NPF. Semakin tinggi dewan komisaris akan menurunkan NPF. Namun dalam penelitian ini menjelaskan bahwa semakin tinggi tidaknya dewan komisaris tidak mempengaruhi NPF.

6. Variabel dewan komisaris independen mempunyai nilai koefisien ke arah negatif yaitu sebesar -0,142754 dan nilai probabilitas sebesar 0,5486. Nilai tersebut lebih besar dari nilai alpha 0,05 , maka dewan yang diproksikan dengan ukuran dewan komisaris independen tidak berpengaruh terhadap NPF, artinya hipotesis $\left(\mathrm{H}_{6}\right)$ yang menyatakan bahwa dewan komisaris independen berpengaruh negatif signifikan tehadap NPF dalam penelitian ini ditolak. Hasil penelitian ini berbeda dengan hasil penelitian Rahman dan Safitrie (2018) yang menyatakan bahwa dewan komisaris independen berpengaruh negatif signifikan terhadap NPF. Semakin tinggi dewan komisaris independen akan menurunkan NPF. Namun dalam penelitian ini menjelaskan bahwa semakin tinggi tidaknya dewan komisaris independen tidak mempengaruhi NPF.

7. Variabel dewan direksi mempunyai nilai koefisien ke arah positif yaitu sebesar 0,262677 dan nilai probabilitas sebesar 0,4070 . Nilai tersebut lebih besar dari nilai alpha 0,05 , maka dewan yang diproksikan dengan ukuran dewan direksi tidak berpengaruh terhadap NPF, artinya hipotesis $\left(\mathrm{H}_{7}\right)$ yang menyatakan bahwa dewan direksi berpengaruh negatif signifikan tehadap NPF dalam penelitian ini ditolak. Hasil penelitian ini berbeda dengan hasil penelitian Aryani (2019) yang menyatakan adanya pengaruh negatif terhadap risiko kredit, artinya semakin tinggi dewan direksi maka risiko kredit akan menurun. Namun dalam penelitian ini menjelaskan bahwa semakin tinggi tidaknya dewan direksi tidak mempengaruhi NPF.

8. Variabel dewan pengawas syariah mempunyai nilai koefisien ke arah negatif yaitu sebesar 0,010745 dan nilai probabilitas sebesar 0,9688 . Nilai tersebut lebih besar dari nilai alpha 0,05, maka dewan yang diproksikan dengan ukuran dewan pengawas syariah tidak 
berpengaruh terhadap NPF, artinya hipotesis $\left(\mathrm{H}_{7}\right)$ yang menyatakan bahwa dewan pengawas syariah berpengaruh negatif signifikan tehadap NPF dalam penelitian ini ditolak. Hasil penelitian ini berbeda dengan hasil penelitian Ekaputri (2014) yang menyatakan adanya pengaruh GCG terhadap NPF. Semakin tinggi GCG akan mampu menurunkan NPF. Namun dalam penelitian ini menjelaskan bahwa semakin tinggi tidaknya dewan pengawas syariah tidak mempengaruhi NPF.

9. Variabel NPF mempunyai nilai koefisien ke arah negatif yaitu sebesar 0,260288 dan nilai probabilitas sebesar 0,0004. Nilai tersebut lebih kecil dari nilai alpha 0,05, maka NPF mempunyai pengaruh negatif signifikan terhadap kinerja keuangan, artinya hipotesis $\left(\mathrm{H}_{9}\right)$ yang menyatakan bahwa NPF berpengaruh negatif signifikan tehadap kinerja keuangan dalam penelitian ini diterima. Hal ini mempunyai arti bahwa semakin rendah atau tinggi NPF maka akan berpengaruh terhadap kinerja keuangan. Hasil penelitian ini sejalan dengan penelitian Nurhayati (2019) yang menyatakan bahwa risiko pembiayaan berpengaruh negatif terhadap profitabilitas.

10. Nilai t hitung dewan komisaris sebesar 1,133336. Nilai tersebut lebih kecil dari nilai t tabel 1,98137, maka NPF dalam penelitian ini tidak dapat memediasi pengaruh antara dewan komisaris terhadap kinerja keuangan, artinya hipotesis $\left(\mathrm{H}_{10}\right)$ yang menyatakan bahwa Non Performing Financing (NPF) mampu memediasi pengaruh antara Dewan Komisaris terhadap Kinerja Keuangan ditolak. Hal tersebut sudah terlihat bahwa tidak ada hubungan langsung antara dewan komisaris dengan NPF. Hasil penelitian ini berbeda dengan penelitian yang dilakukan Setiawaty (2016) yang menyatakan bahwa Good Corporate Governance terhadap kinerja keuangan dengan manajemen risiko sebagai variabel intervening mampu memediasi diantara keduanya.

11. Nilai t hitung dewan komisaris independen sebesar 0,573554. Nilai tersebut lebih kecil dari nilai t tabel 1,98137, maka NPF dalam penelitian ini tidak dapat memediasi pengaruh antara dewan komisaris independen terhadap kinerja keuangan, artinya hipotesis $\left(\mathrm{H}_{11}\right)$ yang menyatakan bahwa Non Performing Financing (NPF) mampu memediasi pengaruh antara dewan komisaris independen terhadap kinerja keuangan ditolak. Hal tersebut sudah terlihat bahwa tidak ada hubungan langsung antara dewan komisaris independen dengan NPF. Hasil penelitian ini berbeda dengan penelitian yang dilakukan Aryani (2019) yang menyatakan bahwa komisaris independen berpengaruh terhadap risiko kredit, dimana semakin tinggi dewan komisaris independen maka risiko kredit semakin rendah dan dalam penelitian ini risiko kredit mampu memediasi pengaruh dewan komisaris independen terhadap kinerja keuangan. 
12. Nilai t hitung dewan direksi sebesar 0,784150. Nilai tersebut lebih kecil dari nilai t tabel 1,98137, maka NPF dalam penelitian ini tidak dapat memediasi pengaruh antara dewan direksi terhadap kinerja keuangan, artinya hipotesis $\left(\mathrm{H}_{12}\right)$ yang menyatakan bahwa Non Performing Financing (NPF) mampu memediasi pengaruh antara dewan direksi terhadap kinerja keuangan ditolak. Hal tersebut sudah terlihat bahwa tidak ada hubungan langsung antara dewan direksi dengan NPF. Hasil penelitian ini berbeda dengan penelitian yang dilakukan Aryani (2019) tentang pengaruh GCG terhadap profitabilitas dengan risiko kredit sebagai variabel intervening yang menyatakan bahwa dewan direksi berpengaruh positif terhadap kinerja keuangan, berpengaruh negatif terhadap risiko kredit dan hasil penelitian ini juga menunjukkan bahwa risiko kredit mampu memediasi pengaruh dewan direksi terhadap kinerja keuangan.

13. Nilai t hitung dewan pengawas syariah sebesar 0,001153. Nilai tersebut lebih kecil dari nilai t tabel 1,98137, maka NPF dalam penelitian ini tidak dapat memediasi pengaruh antara dewan pengawas syariah terhadap kinerja keuangan, artinya hipotesis $\left(\mathrm{H}_{13}\right)$ yang menyatakan bahwa Non Performing Financing (NPF) mampu memediasi pengaruh antara dewan pengawas syariah terhadap kinerja keuangan ditolak. Hal tersebut sudah terlihat bahwa tidak ada hubungan langsung antara dewan pengawas syariah dengan NPF. Hasil penelitian ini berbeda dengan penelitian yang dilakukan Setiawaty (2016) yang menyatakan bahwa risiko kredit mampu memediasi pengaruh antara GCG terhadap Kinerja Keuangan.

\section{PENUTUP}

Berdasarkan perumusan masalah, pengumpulan data, pengolahan data dan analisis data dalam penelitian ini mengenai pengaruh dewan komisaris, dewan komisaris independen, dewan direksi dan dewan pengawas syariah terhadap kinerja keuangan dengan non performing financing sebagai variabel intervening dapat disimpulkan sebagai berikut: 1.) Dewan Komisaris, Dewan Komisaris Independen, Dewan Pengawas Syariah berpengaruh negatif dan tidak signifikan tehadap kinerja keuangan Bank Umum Syariah, artinya semakin bertambah banyak atau tidaknya Dewan Komisaris tidak akan berpengaruh terhadap kinerja keuangan. Dewan Direksi berpengaruh positif dan tidak signifikan tehadap kinerja keuangan Bank Umum Syariah, artinya semakin bertambah banyak atau tidaknya Dewan Direksi tidak akan berpengaruh terhadap kinerja keuangan. 2.) Dewan Komisaris, Dewan Komisaris Independen, Dewan Pengawas Syariah berpengaruh negatif dan tidak signifikan tehadap NPF Bank Umum Syariah, artinya semakin bertambah banyak atau tidaknya Dewan Komisaris tidak akan 
berpengaruh terhadap NPF. Dewan Direksi berpengaruh positif dan tidak signifikan tehadap NPF Bank Umum Syariah, artinya semakin bertambah banyak atau tidaknya Dewan Direksi tidak akan berpengaruh terhadap NPF. 3.) NPF berpengaruh negatif dan signifikan terhadap kinerja keuangan Bank Umum Syariah, artinya ketika NPF mengalami penurunan maka kinerja keuangan akan meningkat dan sebaliknya. 4.) NPF tidak mampu memediasi atau berperan sebagai variabel intervening dalam penelitian ini mengenai pengaruh Dewan Komisaris, Dewan Komisaris Independen, Dewan Direksi dan Dewan Pengawas Syariah terhadap kinerja keuangan Bank Umum Syariah. Dengan kata lain tidak terdapat pengaruh tidak langsung antara Dewan Komisaris terhadap kinerja keuangan melalui NPF.

Berdasarkan hasil penelitian yang telah dilakukan, maka peneliti dapat memberikan saran untuk lembaga perbankan khususnya bank syariah di Indonesia, untuk lebih memaksimalkan kinerja dalam tata kelola yang baik dan juga memaksimalkan dalam menangani risiko-risiko dalam pembiayaan agar risiko berkurang sehingga laba atau kinerja perusahaan meningkat.

Untuk peneliti selanjutnya, apabila ingin meneliti penelitian yang serupa sebaiknya menambah komponen dalam variabel independen ataupun menambah variabel good corporate governance yang lainnya. Selain itu peneliti selanjutnya sebaiknya menambah data yang akan diteliti, karena dalam penelitian ini hasil penelitian belum konsisten, untuk itu diperlukan peneiltian yang lebih mendalam. Dapat dilakukan dengan menambah jumlah yang akan dijadikan sampel. Selain itu juga dapat dilakukan dengan menambah periode laporan untuk pengambilan data. 


\section{DAFTAR PUSTAKA}

Aryani, K.H. (2019). Pengaruh GCG Terhadap Profitabilitas Perbankan Dengan Risiko Kredit Sebagai Variabel Intervening (Pada Perbankan Yang Terdaftar di BEI Periode 20142016). Distribusi: Jurnal Ilmu Manajemen dan Bisnis, 7 (1).

Anita, D.N., Agus Wahyudi Salasa Gama., dan G. Oka Warmana. (2019). Analisis Pengaruh Corporate Governance terhadap Kinerja Keuangan Sektor Perbankan yang Terdaftar di BEI, E-Jurnal UNMAS, 1 (1).

Budiman, F. (2016). Pengaruh Kualitas Penerapan Good Corparate Governance Terhadap Tingkat Pengembalian dan Risiko Pembiayaan Bank Syariah di Indonesia, Muqtasid: Jurnal Ekonomi dan Perbankan Syariah, 7 (2).

Ekaputri, C. (2014). Tata Kelola, Kinerja Rentabilitas dan Risiko Pembiayaan Perbankan Syariah, Journal of Business and Banking. 4 (1).

Eksandy, A. (2018). Pengaruh Good Corporate Governance terhadap Kinerja Keuangan pada Perbankan Syariah Indonesia, Jurnal Akuntansi, 5 (1).

Hanggraeni, D. (2019). Manajemen Risiko Pembiayaan Syariah. Bogor: IPB Press.

Kompas.com. diakses pada 10 Juni 2020.

Nurhayati. (2019). Pengaruh Dana Pihak Ketiga dan Risiko Pembiayaan terhadap Profitabilitas Bank Umum Syariah di Indonesia periode 2008-2017, E-Jurnal UMPWR, 1 (4).

Prasetyo, D., dan Totok Dewayanto. (2019). Pengaruh Karakteristik Dewan Komisaris terhadap Kinerja Perusahaan (Studi empiris pada perusahaan manufaktur periode 20132015), Diponegoro Journal of Accounting, 8 (2).

Putra, B.P.D. (2015). Pengaruh Dewan Komisaris, Proporsi Dewan Komisaris Independen terhadap Kinerja Perusahaan, Jurnal Manajemen Teori dan Terapan, 8 (2).

Peraturan Bank Indonesia PBI No.8/14/2006

Rahman, T., dan Dian Safitrie. (2018). Peran Non Performing Financing (NPF) dalam Hubungan antara Dewan Komisaris Independen dan Profitabilitas Bank Syariah, Jurnal Bisnis dan Manajemen Islam, 6 (1).

Rahmawati, I.A., Brady Rikumahu., dan Vaya Juliana Dillak. (2017). Pengaruh Dewan Direksi, Dewan Komisaris, Komite Audit dan Corporate Social Responsibility terhadap Kinerja Keuangan Perusahaan (Studi kasus pada perusahaan sub sektor pertambangan batu bara yang terdaftar di BEI tahun 2013-2015), Jurnal Akuntansi dan Ekonomi FE.UN PGRI Kediri, 2 (2). 
Setiawaty, A. (2016). Pengaruh Mekanisme GCG Terhadap Kinerja Perbankan Dengan Manajemen Risiko Sebagai Variabel Intervening, Kinerja: Jurnal Ekonomi dan Manajemen, 13 (1).

Sukariana, I.W., and Darma, G.S. (2015). Peran Audit Dalam Pengendalian Internal Serta Pengungkapan Kerugian Material Untuk Good Corporate Governance, Jurnal Manajemen \& Bisnis, 12 (2): 181-194.

Suwarno, R.C., dan Ahmad Mifdhlol Muthohar. (2018). Analisis Pengaruh NPF, FDR, BOPO, CAR dan GCG terhadap Kinerja Keaungan Bank Umum Syariah di Indonesia periode 2013-2017, Jurnal Bisnis dan Manajemen Islam, 6 (1).

Widiastuty, T. (2018). Perbandingan Praktik GCG Bank Syariah dan Konvensional serta Pengaruhnya terhadap Pinjaman Bermasalah, Jurnal Riset Akuntansi dan Keuangan, 6 (2).

Widiatmika, P.H., and Darma, G.S. (2018). Good Corporate Governance, Job Motivation, Organization Culture Which Impact Company Financial Performance, Jurnal Manajemen \& Bisnis, 15 (3): 82-99.

Yana, S.D., dan Nila Sari. (2019). Pengaruh GCG dan Ukuran Perusahaan Terhadap Kinerja Perusahaan Pada BPR Kota Padang, ACONFIBA: Academic Conference of Accounting, 1. 